\title{
Three scenario narratives for a resource-efficient and low-carbon Europe in $\mathbf{2 0 5 0}$
}

\begin{abstract}
Global trends in production and consumption and the associated use of natural resources are far from sustainable. There is a growing recognition of the need to tackle overexploitation of resources, including materials, land, water and carbon. However, transformations to a more resource-efficient economy and society are complex. This paper elaborates three possible scenarios for a resourceefficient economy in Europe. We describe three scenarios and characterize the key differences between them. The basis of the three scenarios - Global Cooperation, Europe Goes Ahead and Civil Society Leads - are very different governance models, worldviews and actors who drive the process. Each scenario encompasses a number of challenges, which are also described. A resource-efficient economy could be advanced through top-down agreements, through market-based mechanisms driving technological solutions, and through bottom-up behavioural changes and community based initiatives focusing on both efficiency and sufficiency. In reality, a combination of these approaches is likely to be required for the achievement of ambitious resource-efficiency targets in Europe.
\end{abstract}

Keywords: Resources, Resource efficiency, Sufficiency, Scenarios, Governance, Sufficiency, Europe 


\section{Introduction}

Global resource extraction is growing at a steadily accelerating rate. Between 1950 and 2010, global material use increased from 5.0 to 10.3 tons per capita per annum (t/cap/a) (Giljum et al., 2014; Schaffartzik et al., 2014). The array of pressing problems associated with excessive resource use and their causes has been widely documented (Behrens et al., 2007). The expansion of the resource base required by human societies is approaching limits both with respect to sources for resource inputs and global capacities of global ecosystems to absorb the outflows. As such, growing extraction of natural resources and their inefficient use has lead to several critical 'planetary boundaries' for environmentally sustainable development, namely climate change, loss of biosphere integrity, landsystem change, and biogeochemical cycles (phosphorus and nitrogen), to be surpassed (Rockström et al., 2009; Steffen et al., 2015). In addition, key resources are likely to become increasingly scarce. For example, Sverdrup et al. (2017) conclude that the supply of key metals such as iron, aluminum, copper and zinc, is likely to peak between 2020 and 2040, with extraction processes likely to exhibit increasing energy intensity and cost.

In the search for approaches to curb such concerns, resource efficiency has received considerable attention worldwide (UNEP, 2011). Within the political arena, resource efficiency has been earmarked as a priority for the overarching development strategy for Europe, through the "Europe 2020" strategy (European Commission, 2010) and is at the core of the "Roadmap to a Resource Efficient Europe" (European Commission, 2011). The Roadmap to a Resource Efficient Europe outlines how Europe's economy can be transformed into an environmentally sustainable one by 2050. In addition, achieving the Sustainable Development Goals (SDGs) will depend on the sustainable management of natural resources. Some goals and targets explicitly address natural resource management (e.g. target 12.2) and decoupling of economic growth and natural resource use (target 8.4). Hence, it is increasingly acknowledged that economic growth and human wellbeing must be decoupled from resource use and associated environmental impacts. The International Resource Panel of the United Nations Environment Programme provide an overview over the challenges, opportunities and potential policy measures for 'decoupling' (UNEP, 2011, 2014). Most resource and environmental policy efforts have thus far concentrated on keeping the growth rate of resource use and environmental consequences lower than the rate of economic growth (relative decoupling), however various studies conclude that an absolute reduction in resource extraction and environmental consequences is required, either as economic growth continues (absolute decoupling) (Conte Grand, 2016; see also Fedrigo-Fazio et al., 2016), or if this is not possible, at the expense of economic growth (e.g. Martínez-Alier et al., 2010). However, the challenges of achieving (particularly absolute) decoupling are numerous, and discussed further in Section 4.

On a practical level, in some EU member states (e.g. Germany, UK, Austria) as well as in China, Japan and South Korea, improving the efficiency of resource use is already a political objective. However, prevailing efforts have only led to incremental improvements in absolute levels of resource consumption. Current resource policy instruments and goals remain scattered and are not able to deliver the required progress to solve pressing issues around global resource use. Government policy efforts often rely on individual measures and concentrate on qualitative and operational objectives, while specific absolute reduction targets for different raw materials and/or sectors remain limited (Bahn-Walkowiak and Steger, 2015; Bleischwitz et al., 2012).

To address these challenges the POLFREE (Policy Options for a Resource-Efficient Economy) project (October 2012 - March 2016) explored new concepts and paradigms that can bring about decoupling. 
This paper describes the work in the POLFREE project to develop a vision for a resource-efficient economy in the $\mathrm{EU}$ (O'Brien et al., 2014) and three possible narrative scenarios for achieving that vision by 2050 . The narratives and analysis aim to inform policy-makers, firms and civil society actors by illustrating how distinct governance approaches might lead to resource efficiency (and sufficiency) with different economic and social structures in Europe. Efficiency means that material and energy inputs per unit of production are improved whereas sufficiency refers self-imposed restriction of consumption that in turn leads to lower environmental pressures (Alcott, 2008; Schanes et al., 2016b).

The structure of the paper is as follows. Section 2 introduces the scenario development process. Section 3 presents three scenarios for a resource-efficient Europe. In Section 4, we discuss the challenges that these scenarios pose. The paper closes with some concluding remarks on the scenario development process and the results.

\section{Exploratory scenarios and backcasting}

"Scenarios are descriptions of journeys to possible futures. They reflect different assumptions about how current trends will unfold, how critical uncertainties will play out and what new factors will come into play" (UNEP, 2002, p.320).

As the quote above demonstrates, scenarios are not predictions of the future. Scenarios describe how the future might unfold. They explore the possible, not just the probable, and challenge users to think beyond conventional wisdom.

There is a range of different approaches to scenario development and these have been described, for example, by Van Notten et al. (2003), Börjeson et al. (2006) and Rothman (2008). The approaches most relevant to the work reported in this paper are exploratory scenarios and backcasting. Exploratory scenarios look at several plausible futures in order to understand better the implications of current uncertainty about future developments of environmental, social and economic factors (see for example Peterson et al., 2003). However, since exploratory scenarios do not necessarily provide insights on how a desirable solution could be attained (Robinson, 1990), back-casting has been developed. The normative approach of backcasting consists of working backwards from a particular desired future (Quist et al., 2011; Quist and Vergragt, 2006; Robinson, 2003) to describe how this future state could be achieved.

Scenario developers have noted that the exploratory and the backcasting approaches both have advantages and disadvantages Kok et al. (2015) and van Vliet and Kok (2015) argue that there is an added value in combining the two approaches. In the combined approach, the exploratory scenarios provide a socio-economic context in which to back-cast from a desired future. In the study reported here such a combined approach is taken.

\subsection{The development of three exploratory scenarios}

Most scenario development processes begin with an identification of key uncertainties in the drivers of change in the future. Depending on the context, these drivers could be population change, economic development, concern for the environment, governance models, inequalities in society and a host of other factors (Jäger et al., 2007). Since the focus of the POLFREE project was on resource efficiency, an expert workshop of the project consortium decided that the key uncertainty to be used for the exploratory scenarios is the governance model for resource use. This decision was based on a literature review and analysis carried out in the project (O'Keefe et al. 2014).

This key uncertainty is based on a broad characterisation of governance, encompassing traditional state led institutions and actors, as well as those emerging from individuals, community, not-for-profit 
and business groups, with the full suite of formal and informal mechanisms (O'Keefe, 2014). Governance mechanisms are categorized as "top-down" or "bottom-up". "Top-down" mechanisms are led by state actors, often co-ordinated through international institutions. "Bottom-up" mechanisms originate from multiple sources from the not-for-profit, academic, business and community sectors. "Bottom-up" governance mechanisms are non-binding but can prepare the ground for experimentation and development of norms and practices that may become accepted and thus more deeply embedded in society (Middlemiss and Parrish, 2010).

O'Keefe et al. (2014) propose, based on the analysis of resource governance models that three potential futures can be envisaged:

- A multilateral world with all countries recognising the importance of coordinated action;

- A coalition-driven world in which collaboration is occurring but it is in smaller coalitions rather than full multilateral processes;

- A world of unilateral action and bilateral agreements.

Based on this broad categorization of potential future resource governance models, the POLFREE project consortium decided to explore the following three scenarios:

GLOBAL COOPERATION: A multilateral world with coordinated action to reduce resource use.

EUROPE GOES ALONE: A coalition-driven world in which Europe plays a strong leadership role in the transition to a resource-efficient economy;

CIVIL SOCIETY LEADS: A scenario in which bottom-up actions for resource efficiency and sufficiency are implemented in Europe.

Thus, the three exploratory scenarios provide three different contexts for achieving a resourceefficient economy: one in which there is full global cooperation and a top-down governance model; one in which there is some collaboration with other countries but Europe essentially develops its own top-down governance of resource use; and one in which bottom-up initiatives and unilateral actions dominate in reducing resource use.

\subsection{The desired future for back-casting}

To support the back-casting and for a model-based evaluation of the scenarios, a broad description of the desired future in $\mathbf{2 0 5 0}$ was based on a literature review of a range of available visions and related processes that had created a picture of a sustainable world in the future. Key publications examined in the literature review included the "Roadmap to a resource efficient Europe" (European Commission 2011), "Vision 2050 - the new agenda for business" from the World Business Council for Sustainable Development (WBCSD 2010), "World in Transition: A social contract for sustainability" by the German Advisory Council on Global Change (WBGU, 2011) and the "The Great Transition: The Promise and Lure of the Times Ahead" by the (Raskin et al., 2002). The desired future of a resource-efficient Europe in 2050, based on this literature review, is described in detail by O'Brien et al. (2014). It is characterized by three "pillars": the safe and fair use of resources; a healthy, educated, equitable and just society; and a transformed economy. Furthermore, since the focus of the POLFREE project was on achieving a resource-efficient economy, the description of the desired future included specific goals for the efficient use of resources (materials, land, water and carbon). These goals were based on a further literature review. Key sources were:

- Roadmap to a Resource Efficient Europe (European Commission, 2011);

- Vision 2050 - the new agenda for business (WBCSD, 2010);

- Decoupling Natural Resource Use and Environmental Impacts from Economic Growth (UNEP, 2011); 
- Roadmap 2050 (European Climate Foundation, 2010);

- Power Perspectives 2030 (European Climate Foundation, 2011);

- Assessment of Resource Efficiency Indicators and Targets (BIO Intelligence Service, 2012);

- Sustainability Scenarios for a Resource Efficient Europe (Cambridge Econometrics, 2011).

The description of the desired future was presented to, discussed and amended by a broad group of European stakeholders during a workshop in Brussels in December 2013. The participants from outside the project were invited on the basis of their involvement with issues related to resource use and their involvement in related decision-making processes. It was also important, since this project was supported by the European Commission, to ensure participation from across the European Union. The invitation list was compiled using suggestions from the project team, as well as taking key names from the literature reviews mentioned above. The 24 participants at the workshop were from the project team, the European Commission (DG Climate Action, DG Environment), government (e.g. DEFRA,UK), business and industry (WRAP, McKinsey) international organisations (UNEP, OECD), civil society organisations (e.g. Friends of the Earth) and research organisations working on resource-related issues. During the half-day meeting, there were two input presentations: one on the POLFREE project as a whole and one on the desired future resource-efficient economy developed by the project team. This was followed by discussions in small groups, which provided feedback on the desired future state. After the workshop, the project team modified the description of the desired future in accordance with the comments made by the participants.

\subsection{Elaborating narratives for a resource-efficient Europe}

The narratives for the three scenarios (Global Cooperation, Europe Goes Alone and Civil Society Leads) were elaborated based on extensive literature reviews that provided details and steps that need to be taken in each scenario for realizing the desired endpoint by 2050. The scenarios were presented to stakeholders on three large murals at a workshop in Brussels in June 2014. Working directly with these murals, the participants added further actions for enhanced resource efficiency in Europe within the socio-economic context of each scenario. As with the first workshop (Section 2.2) the 20 stakeholders included representatives from the European Commission, business and industry, civil society and the research community. Each stakeholder group provided useful inputs in their areas of competence for the development of the scenarios. A questionnaire filled out at the end of the workshop showed that for $2 / 3$ of the respondents the content of the workshop was relevant to their work. Half of the respondents felt that there was too much material presented on the murals. The main missing element identified at the workshop was the issue of finance. After the workshop, the scenarios were further developed using the contributions of stakeholders and finally, visualisations with timelines were created for each scenario. The desired end-point and the three exploratory scenarios were used in a modelling exercise to test how well each scenario achieves the end-point. This modelling work is described by Distelkamp and Meyer (2017).

\section{Three Scenarios for a resource efficient and low-carbon Europe}

Using narratives, this section outlines the three scenarios for a resource-efficient economy in Europe. As recent publications have shown (e.g. Milojević and Inayatullah, 2015; Raven and Elahi, 2015), narratives or storytelling are a central element of scenario development and provide an exploration of multiple aspects of possible futures. Table 1 gives an overview of the three scenarios and their key characteristics.

Table 1 Outline of the three scenarios

\begin{tabular}{|l|l|l}
\hline Global Cooperation & Europe Goes Ahead & Civil Society Leads
\end{tabular}




\begin{tabular}{|c|c|c|c|}
\hline Governance level & Global & EU & National, regional, local \\
\hline Agents of change & $\begin{array}{l}\text { International Organisations, Central } \\
\text { Governments }\end{array}$ & $\begin{array}{l}\text { Central Governments, Large } \\
\text { companies }\end{array}$ & $\begin{array}{l}\text { Civil society, Social movements; } \\
\text { Small and medium sized enterprises } \\
\text { (SME's), NGO's }\end{array}$ \\
\hline Objects of change & $\begin{array}{l}\text { Mostly production processes but } \\
\text { also consumption behaviour }\end{array}$ & $\begin{array}{l}\text { Mostly production processes but } \\
\text { also consumption behaviour }\end{array}$ & $\begin{array}{l}\text { Social innovations, awareness, } \\
\text { social practices and lifestyles, } \\
\text { norms and values, infrastructure }\end{array}$ \\
\hline Policy instruments & Global regulations and taxes & $\begin{array}{l}\text { Ecological tax reform } \\
\text { Design of taxation instrument in a } \\
\text { way that avoids problems with } \\
\text { international competitiveness. }\end{array}$ & $\begin{array}{l}\text { Information, knowledge transfer, } \\
\text { network building, Infrastructure } \\
\text { provision }\end{array}$ \\
\hline Economic model & Green growth & Green growth with industrial policy & $\begin{array}{l}\text { Beyond growth. Critique of } \\
\text { capitalism, growth and GDP } \\
\text { obsession. }\end{array}$ \\
\hline Production & $\begin{array}{l}\text { Focus on firms, 'green' products, } \\
\text { eco-efficient production processes, } \\
\text { and 'greening' of supply chains } \\
\text { (globally). }\end{array}$ & $\begin{array}{l}\text { Focus on firms, 'green' products, } \\
\text { eco-efficient production processes, } \\
\text { and 'greening' of supply chains (in } \\
\text { EU). }\end{array}$ & $\begin{array}{l}\text { 'New economics', grassroots } \\
\text { initiatives, decentralized and local } \\
\text { production, Product- services, } \\
\text { sharing economy, de-growth. }\end{array}$ \\
\hline Consumption & Green consumption, recycling & Green consumption, recycling & $\begin{array}{l}\text { Consumption reduction, sufficiency, } \\
\text { product-services, waste prevention }\end{array}$ \\
\hline Mobility & $\begin{array}{l}\text { - High-speed international trains } \\
\text { - A set of regulations and } \\
\text { economic instruments favouring } \\
\text { e-mobility } \\
\text { - Seamless transportation } \\
\text { infrastructures } \\
\text { - Intelligent traffic management } \\
\text { (ICT) } \\
\text { - International shipping and } \\
\text { aircraft increases, fuelled by } \\
\text { new low-carbon engines } \\
\text { - Large-scale deployment of } \\
\text { hydrogen, electric vehicles and } \\
\text { other new engines fuelling } \\
\text { resource-efficient cars } \\
\text { - International tourism boosted }\end{array}$ & $\begin{array}{l}\text { - } \text { Fuel efficiency } \\
\text { - New low-carbon engines, } \\
\text { resource efficient materials and } \\
\text { design } \\
\text { - Cleaner energy use through new } \\
\text { fuels and propulsion systems } \\
\text { - Better use of network through } \\
\text { information and communication } \\
\text { systems } \\
\text { - Optimised performance of } \\
\text { multimodal logistic chains }\end{array}$ & $\begin{array}{l}\text { - High-efficiency intermodal } \\
\text { transportation options } \\
\text { combining public transport, } \\
\text { biking and walking } \\
\text { - Sharing concepts of cars and } \\
\text { bikes } \\
\text { - Integrated, system spatial } \\
\text { planning reduces travel needs } \\
\text { - People work close to where they } \\
\text { live } \\
\text { - International travel reduced }\end{array}$ \\
\hline Housing & $\begin{array}{l}\text { - Subsidies for investment in the } \\
\text { energy efficiency of buildings } \\
\text { - Rapid replacements of old } \\
\text { buildings } \\
\text { - Zero-energy and highly material- } \\
\text { efficient construction of new } \\
\text { buildings } \\
\text { - Industrial production in } \\
\text { - Large-scale companies operating } \\
\text { - Sustainable Mega-Cities }\end{array}$ & $\begin{array}{l}\text { - Highly resource-efficient } \\
\text { renovation of existing buildings } \\
\text { - Zero-energy and highly material- } \\
\text { efficient construction of new } \\
\text { buildings } \\
\text { - Recycling of non-hazardous } \\
\text { construction materials and } \\
\text { demolition waste } \\
\text { - Greater technology integration } \\
\text { (e.g. building integrated } \\
\text { photovoltaics (BIPV)) }\end{array}$ & $\begin{array}{l}\text { - Renovation and refurbishment } \\
\text { of existing buildings sourced by } \\
\text { high rates of recycled materials } \\
\text { from urban mining } \\
\text { - Smaller homes } \\
\text { - Modular construction enabling } \\
\text { easier repair, rebuilding and } \\
\text { rearranging of the building } \\
\text { - Efficient heating and cooling } \\
\text { with the natural advantages of } \\
\text { earthen walls, rooftop gardens, } \\
\text { and indoor vegetation }\end{array}$ \\
\hline Food & $\begin{array}{l}\text { - A regulation for water } \\
\text { abstraction of agriculture } \\
\text { - An information program to } \\
\text { avoid food waste } \\
\text { - A tax on meat consumption and } \\
\text { - An information program to } \\
\text { reduce the yield gap in } \\
\text { agriculture } \\
\text { - Food chains shifted towards the } \\
\text { remit of government, with new } \\
\text { integrated partnership food } \\
\text { enterprises. } \\
\text { - EU cooperation increases and } \\
\text { leads to specialization of } \\
\text { intensive farming. } \\
\text { - Niche products can be marketed } \\
\text { on a global basis. }\end{array}$ & $\begin{array}{l}\text { - Advances and efficiency } \\
\text { improvements through new } \\
\text { technologies in industrial } \\
\text { agriculture. } \\
\text { - Modest increase in organic } \\
\text { agriculture }\end{array}$ & $\begin{array}{l}\text { - Local food production by smaller } \\
\text { businesses } \\
\text { - Almost all food produced is } \\
\text { organic } \\
\text { - Specialized and niche products } \\
\text { - Fertilisers and pesticides have } \\
\text { been substantially reduced } \\
\text { - Food supply chains are generally } \\
\text { - } \text { short } \\
\text { - High self-sufficiency at national } \\
\text { level } \\
\text { - Less meat consumption and } \\
\text { food waste }\end{array}$ \\
\hline Energy & $\begin{array}{l}\text { - Large scale international grids, } \\
\text { with more efficient direct } \\
\text { current systems, to enable } \\
\text { power sharing between the } \\
\text { solar resources of North Africa, } \\
\text { hydropower and biomass } \\
\text { resources of Scandinavia and so } \\
\text { on } \\
\text { - A diversity of supply strategies } \\
\text { (renewable and conventional } \\
\text { energy, nuclear) }\end{array}$ & $\begin{array}{l}\text { - Carbon prices split between } \\
\text { world regions. The EU adopts } \\
\text { border tax adjustments } \\
\text { - EU energy partnership with } \\
\text { Russia and neighbourhood } \\
\text { policy with Northern Africa } \\
\text { brings new gas supply } \\
\text { - Cooperation within Europe (e.g. } \\
\text { grids) }\end{array}$ & $\begin{array}{l}\text { - Energy infrastructure is largely } \\
\text { decentralised, flexible and } \\
\text { collaborative. } \\
\text { - Micro-generation and more } \\
\text { localized renewable sources. } \\
\text { - Centralized large-scale systems } \\
\text { and decentralised systems work } \\
\text { together and depend on each } \\
\text { other. }\end{array}$ \\
\hline
\end{tabular}




\subsection{Global Cooperation}

Central to the Global Cooperation scenario is a globally shared commitment and collective agreement on the need to pool joint resources and powers to promote the sustainable use of resources and to tackle climate change. Strong international coalitions with all countries worldwide are the key to achieving globally agreed targets. This is supported by forging alliances across all nations and engaging governments in multilateral processes where countries reinforce and spur each other on to take action. Multilateral processes are the driving forces for making substantial progress and developing solutions at global and national levels.

\section{European actors and governance}

A top-down form of 'global governance' ensures connected international efforts that trigger strong, international structures of technology-based initiatives and financial arrangements and generate collective action at a global level through transnational connections. An international resource agency supports global information gathering and dissemination, coordinates activities on resources and supports the development of global voluntary and binding agreements that target resources. The EU is a key and influential partner in international governance structures and is able to scale up its policies and instruments to the global level. Notably, the EU supports other countries in their decarbonisation efforts through technology transfer and funding.

\section{European industry and innovation}

The predominant economic model adopted in Europe is that of green growth, in which economic development is pursued in an environmentally sustainable manner. The EU still measures progress through GDP, which continues to grow with rates accelerated by high demand for consumer goods. Influential, multinational companies dominate the market in Europe. Their global reach, their ability to innovate, scale up and roll out technology, as well as their access to private finance, is essential for the scale and speed of the reduction of greenhouse gas emissions.

High levels of technological advancement in resource efficiency driven by international standards ease the pressure of resource use despite continued consumerism. More resource-efficient consumption and production patterns are delivered by international and European level regulations, policies and initiatives. Innovation is funded through large, centralised institutions including major public and private partnerships, large philanthropic organisations and through international scale market mechanisms. Technology transfer spurs improvements in resource efficiency of industrial processes, which is a key aspect of global agreements on climate change and resource efficiency. These stimulate a growth of innovative technologies and commitments to investment in research and development within Europe. The growth of global product agreements also supports the move towards resource efficiency. Corporate responsibility and transparency are high, facilitated and measured through global reporting systems.

\section{European energy}

European power demand is high in this scenario due to increasing populations and the important role of high-tech applications. International agreements on climate change lead to significant incentives for the decarbonisation of the power sector and foster a significant diversification of supply strategies in Europe and across the world. The centralized energy system includes a combination of fossil fuels (with abatement technologies and including unconventional sources), bioenergy and other renewables (primarily wind, solar and hydropower) connected through international grids.

\section{European food and agriculture}


A growing global population paired with a strong focus on income, growth and consumption and a need for bio-energy resources in this scenario generates intense pressures on land for food production. A global agricultural market based on highly specialised intensive farming techniques and innovation further increase the efficiency and productivity of industrial agriculture. European citizens benefit from extensive global supply chains to maintain a varied and globally sourced diet. The focus is on industrial, processed food with high levels of consumer choice, delivered through a patchwork of large global chains of retailers and restaurants. An internationally harmonized system of labels for food provides consumers with information on global impact (land use, water use, greenhouse gas emissions and resource use) of the food they buy.

\section{European mobility}

Europeans travel extensively around the world for both business and personal reasons. Whilst telecommunication technology such as video conferencing displaces some trips, overall trip numbers remain high due to interconnected global societies. The early introduction of strong standards to improve fuel efficiency through new engines, improved lighter materials and designs of conventional vehicles and ships alleviate some of the environmental effects that arise from extensive use of cars, buses, trucks and ships. Additionally, public procurement strategies as well as research and innovation efforts, particularly on high-capacity batteries using advanced materials, fuel cells and hydrogen, ensure rapid development and deployment of the key technologies for a shift to plug-in hybrid cars and electric cars. Widespread adoption of electric vehicles and the associated infrastructural development progresses through investment and clear and strong policy commitment. Public transport networks are also extensive and interconnected nationally and internationally, providing a fast and efficient service. In Europe and beyond, a dense high-speed rail network is established and the majority of medium-distance passenger transport is by rail. Air travel is still popular, within Europe and further afield, again powered by fuel-efficiency improvements, increasing aircraft efficiency and the commercialization of "alternative" low-carbon aviation fuels.

\section{European buildings}

Europe is densely populated with the vast majority of people living in cities. Living spaces are smaller to accommodate increasing densities. There is significant pressure on these cities to become resource efficient - in building construction and operation, and in the urban planning of the city as a whole. High international standards for buildings apply to both existing and new housing stock and support rapid roll out. Standards for new buildings and refurbishment programmes support significant innovations in zero-energy houses and material-efficient building materials as well as improvements in material reuse and high quality recycling of construction materials.

\subsection{Europe Goes Ahead}

Europe Goes Ahead is a scenario in which resource efficiency and efforts to reduce greenhouse gas emissions are key opportunities to boost the EU's competitiveness and protect it against the impacts of climate change and resource scarcity. Europe acts as a global forerunner in making significant advancements in technological innovations to spur resource efficiency and decarbonisation across all sectors of the economy. It receives backing from European governments, large-scale corporations, businesses and technology/infrastructure manufacturers in supporting major programmatic and legislative developments. However, the pace of change outside of Europe remains fragmented and slow. The changes in the areas of Buildings and Mobility are the same as in the Global Cooperation scenario but implemented mainly in Europe only. 
In this scenario, there is a failure to agree on coordinated global action. This lack of agreement leads to a low commitment more broadly to global multilateral processes. Although formal international cooperation is low, Europe continues to play an important role in global politics through its influence on global supply chains. Europe takes leadership in global markets for clean production and by doing so it exerts international pressure to find solutions for resource and climate problems and increases its reputation as a responsible international stakeholder. Border tax adjustments and regulations incentivise and require global producers entering into the European market to adapt to new European environmental standards. Within Europe, relationships between nations are strong and collaborative projects and programs are established. Individual Member States work on parallel tracks of high government intervention and partnerships with others to ensure that decarbonisation and resource efficiency commitments remain on track. Despite the relatively limited importance of global cooperation, progress on the international stage continues through plurilateral agreements and 'coalitions of the willing'.

\section{European industry and innovation}

As in "Global Cooperation", the predominant economic model adopted in Europe is that of green growth. "Europe Goes Ahead" is highly technology-oriented and pursues a path that combines the pursuit of high economic growth with climate and resource responsibility. The transition to an environmentally sustainable and socially inclusive economy is triggered by ground-breaking ecoinnovations. Innovation focusing on efficiency improvements - including product dematerialization, eco-substitution, decarbonisation, energy efficiency, intensifying production and servicing - is central to this scenario, which aims to decouple consumption and environmental impacts. Many multinational companies within Europe lead the charge in efficiency improvements, especially in areas where they see economic benefit.

European targets and product standards as well as incentives to invest more in research and development drive the design and implementation of innovations for greater resource efficiency. Strong European regulations, appropriate price signals and clear environmental information (e.g. ecolabelling) play a powerful role to stimulate "green" consumption and production. Corporate responsibility and transparency is high, facilitated and measured through European systems of reporting for both companies within and those trading with Europe. A divergence in standards between Europe and the rest of the world, and a need for high levels of investment to meet the resource efficiency standards set by the EU, leads to a dominance of large regionally based companies that are specialised to meet the demands of the European market.

\section{European food and agriculture}

European citizens maintain a high quality and varied diet delivered predominantly through regional supply chains, supplemented by restricted access to global supply chains. All food is labelled according to its sustainability characteristics in line with European standards and similar requirements are placed on imported food from outside the Union. In order to mitigate upstream agricultural emissions, efficiency-focused technological and managerial approaches such as productivity improvements and optimized fertilizer inputs are a priority. A significant reduction of meat consumption is achieved through a mixture of external measures, such as high prices on meat resulting from the pricing of externalities associated with meat production.

\section{European energy}

European power demand is high in 2050 (although not as high as in the "Global Cooperation" scenario) due to increasing populations, high-tech lifestyles and only moderate success in demand-reduction initiatives. Electrification of the transport sector and for heating and cooling in buildings is extensive. This high demand leads to a strong diversity in energy production technologies including some 
innovative approaches to renewable energy generation which are absent in the "Global Cooperation" scenario due to the need for rapid deployment to meet European demand. The energy system, which is centralised, includes a combination of fossil fuels (with appropriate abatement and including nonconventional sources), bioenergy and other renewables (wind, solar, wave and tidal) connected in European-wide grids. A European energy partnership with Russia and neighbourhood policy with Northern Africa provides additional gas supply.

\subsection{Civil Society Leads}

Stagnation in decision-making processes at the European and Member State levels, a continued lack of growth in the economy and a reduction in happiness stemming from poor work/life balance lead to a move away from traditional industries and work-life patterns. A groundswell of local action leads to decentralized movements where citizens' knowledge, aspirations, expertise and needs build initiatives from the bottom up. Citizens and citizen movements become more active in solving local social, environmental and economic problems and play a powerful aggregate role in accelerating the transformation towards resource efficiency and decarbonisation. Defined through inclusive dialogue and participation, citizen-led approaches generate new visions of the future and pathways to achieve those visions. In this way, the transition to lifestyles that are both efficient in use of resources and sufficient in terms of meeting basic needs is deeply linked to the immediate concerns and perceptions lives and livelihoods of the citizenry. Communities working as towns, cities, states, neighbourhoods and groups of like-minded individuals, collaborate to set their own resource-efficiency and emissions targets and provide examples of successful implementation, which in turn lead to some enabling and supporting national government policies.

\section{EU actors and governance}

Civil Society Leads is a scenario in which the transition is a predominantly bottom-up process. Local communities, NGOs and activist groups together with municipalities take responsibility for their lead role in the transition to a resource-efficient economy and trigger action in designing, implementing and governing local solutions.

This scenario is characterized by weak global co-operation due to no agreement on coordinated action on decarbonisation. Whilst some countries take some action, it is uncoordinated, patchy and lacks ambition. The $\mathrm{G} 20$ fail to make a strong contribution to global governance of resource efficiency due to differing national positions and priorities. Some progress on technological collaboration is made but the $\mathrm{G} 20$ is not able to engender support from other nations. Global non-governmental networks and partnerships remain and are aligned strongly along ideological lines.

Europe is no longer a key player in the international governance arena due to its inward looking focus, its lack of alignment with other social and economic models globally and loss of significance as a global consumer and trade partner. Trade with countries outside the EU declines as a result of the ideological shift, and the much lower demand for goods arising from reduced consumption and the reduction in the size of the economy. Less money is available for both individuals and public investments. Resource scarcity is also a concern in the EU, due to the lack of interaction with the global market and a reduction in the economic power of the EU. Where funding from public bodies is available, it focusses on societies and education, to facilitate them in addressing the climate change and resource challenges.

Within the EU relationships remain strong but are led more by organisations within Member States seeking collaboration and ideological alignment. A change in the balance of power and financial means occurs between central and local/regional governments, in favour of the latter. The EU and its member states do not lead the transition, but create the appropriate conditions for this bottom-up process to develop and to support implementation. 


\section{European industry, innovation and the economy}

Innovation is primarily driven by consumer demand rather than regulation and is based on common pools of innovative technologies, co-developed in a spirit of open source and open innovation. Funding comes from communities through crowd funding, community groups and partnerships between SMEs, supplemented and enabled rather than led by public bodies. The economic and financial context of this scenario, however, is not so favourable for capital-intensive technologies and infrastructures to develop on a large scale. There is no clear policy support for this type of technology except for ICT and high-speed train networks. The emphasis in this scenario is on user-centred designs of innovation that produce locally based, smart and creative products. It is social innovation that stimulates lifestyle changes through, for example, new online or offline communities and networks that share knowledge, ideas, tools, solutions and experiences. Web and mobile technologies continue to play a critical role in building sharing communities. A large number of scientific and social entrepreneurs throughout Europe are important change agents. Supply chains in all areas are shorter than in the other scenarios, with more local networks of suppliers working together to build collaborative and sustainable methods of production and delivery to market. Most products, from mobile phones to buildings, are of high quality. They are made from renewable resources, can easily be repaired and upgraded and provide a large amount of service to their users. Furthermore, they can be recycled at the end of their life span.

GDP is no longer used as a measure of progress. Instead, health, happiness and an individual's ecological rucksack are among the aspects measured. Quality of life (e.g. health, holistic education, social interactions, well-being) is prized over economic growth and increasing output (GDP). Due to voluntary reduction in consumption, the need for paid labor and income decreased. By 2050, the working week is decreased to 20 hours or less and full time jobs are shared among people. People devote much more of their time to leisure and pursue more community activities and public service (such as care for children and the elderly).

\section{European food and agriculture}

On the production side, widespread investment into R\&D has resulted in improvement in diversified land production systems like organic farming, permaculture and agro-ecologic farming. The integration of scientific and local knowledge advances agricultural practices on both small and large-scale farms. Specialized and niche products are widespread and this helps to repopulate the countryside and preserve local culture. The focus in this scenario is on rural development and setting the framework conditions to empower people, strengthen capacity building and improve local conditions. A strong connection between farmers and consumers ensures that food is supplied by community-supported agriculture and much food is distributed through co-operatives and farmers' markets. Growing food in urban farming circles as a supplement to the intensive organic production practiced on traditional farms is a part of everyday life. Diets are guided by conscious practices that lead to a healthier way of life of European citizens and to an overall reduction of food overconsumption and decreasing amounts of food waste. There is a reliance on mainly local and seasonal produce, some of which has been rediscovered as a result of reduced dependence on global supply chains. By developing awareness and collective supporting networks, people choose to adopt vegetarian and low animal product consumption.

\section{European mobility}

In 2050 all major cities are almost free of individually owned cars. Cities offer variable multimodal transportation options. These are supported by well-developed bicycle lanes, safe and well-designed footpaths and a well-planned, secure and subsidised public transport network, Public bike sharing, public renting services for shared electric vehicles and transport on demand for disabled people are ubiquitous. Investment in new motorways and airport infrastructures is low. In contrast, a European high-speed train network for passengers and freight connecting European core cities continues to be 
developed. The huge share of work-related mobility and commuting is reduced by the expansion of teleworking, reviving regions and by reorganization and reduction of working hours. Goods and freight transport in cities is now carried out by electric vans (for small to medium-sized goods) and by zeroemission lorries and trucks.

\section{European buildings}

Most Europeans live in cities in socially innovative and resource-, water- and energy-efficient modes of housing such as co-housing communities, urban co-ops and communes. There is a large movement of collective multi-stakeholder and participatory approaches to urban planning and the design of transport and other infrastructure. These approaches support compact, complex and efficient cities with strong social cohesion to promote sustainability and well-being. Reorganisation of the structure of urban development and especially of public space in core cities, gives more space to pedestrians, bicycles and public transport and provides shared public space e.g. for recreation and urban farming.

\section{European energy}

The EU follows the principle of "food first" for using cropland. While biomass does contribute to energy supply, this biomass is mainly from residues and organic waste. Europe plays a role in aiding the establishment of energy crops on degraded soils abroad. These crops are used in local energy networks (e.g. combined heat and power units). Decentralised individual- and community-owned renewable power generation complements large-scale centralised plants (particularly nuclear and remaining fossil fuel, along with offshore wind). A significant number of power grids are brought under community or local government ownership. Electrification leads to an even higher percentage of final energy demand than in the other scenarios. Fracking takes place in some regions, with significant community ownership/benefit-sharing.

\section{Discussion on challenges inherent in the different scenarios}

Using a mix of expert-based analysis and participatory processes, we have developed three plausible but very different scenarios for a resource-efficient Europe in 2050. Distelkamp and Meyer (this issue) use modelling techniques to explore the implications of these scenarios further. Each scenario demonstrates different kinds of challenges to the achievement of a resource-efficient economy. In this section, we discuss these challenges based on analysis of the scenarios made by the project team using relevant literature.

Global Cooperation through the establishment of various global conventions, agreements and initiatives, has been often been the default objective for addressing a range of environmental problems. Proponents cite the global commons nature of greenhouse gas emissions and climate change, and the deep global interconnection of economies and supply chains that mean anything less than global co-operation produces sub-optimal solutions. However, generating collective action of relevant global actors to work together to use resources more efficiently is notoriously challenging. Milligan (this issue) give an extensive overview of the prospects and challenges around global governance. Here, we highlight some of the key challenges:

- Given the currently weak international policy architecture, particularly around environmental issues, combined with the fact that international organizations working on resource efficiency do currently not have legal powers or the capacity to enforce agreements on resources building global and legally-binding frameworks would appear difficult (Schmitz and Scoones, 2015). 
- Identifying and forging alliances across different actors, spatial boarders, sectoral boundaries, and across globalised value chains would be highly complex (Milligan, this issue).

- National interests and aims frequently block or slow down attempts of globally led collective action for sustainable resource use.

- Environmental global governance becomes distorted by existing configurations of power (Fuchs et al., 2016).

- Aligning international trade law and national environmental laws and other international and national legal regimes such as binding agreements, e.g. of the World Trade Organization, might prove to be challenging (Bahn-Walkowiak and Steger, 2015; Schmitz and Scoones, 2015).

- Transitional and developing countries have different ideas on 'just' solutions and about how obligations should be shared.

- The efforts of international institutions is critically scrutinised for exhibiting democratic deficits and for generating resistance among societal actors who feel affected by these international decisions and want to participate in the decision-making, which in turn undermines societal acceptance of international institutions (Zürn, 2004).

The Europe Goes Ahead scenario represents a traditional policy approach pursued by the European Commission to reduce human impacts on the environment through technological change, emphasizing resource efficiency and the development of renewable energy sources. This scenario calls for accurate representation of nature's economic value in the market, much greater government intervention in the form of strong economic instruments, and a market system geared towards green growth. Critiques argue that current Green Growth and Green Economy plans are often too vague and lack urgent measures to reduce Europe's over-consumption of energy, water and land, and fall short of introducing innovative ideas and new policies for how to redefine the relationship between economic growth, material wealth and human well-being (Borel-Saladin and Turok, 2013). They often adopt a traditional economic paradigm, in which economic growth is primarily achieved through technological innovations that boost resource efficiency and thus maximize utility (economic output) by minimizing costs (economic input). The intention in this scenario (and of the Global governance scenario) is not to deeply change the system, but to alter the current production processes and the products that are consumed.

Overall, although regional groupings such as the European Union in the Europe Goes Ahead scenario potentially have legal powers to adjust political framework conditions and therefore could trigger environmental legislation, their realization proves to be difficult for the following reasons:

- European efforts often fail due to diverging interests and resistance of different member states (Adger and Jordan, 2009).

- Green growth and win-win solutions are criticised for over-optimism and over-simplification of challenges around resource use and climate change (Borel-Saladin and Turok, 2013).

- Significant hopes to achieve the green economy are pinned on technology, which many believe will promote the transition to a resource efficient economy are often regarded to be insufficient to meet the most pressing sustainability challenges of the twenty-first century (Lorek and Spangenberg, 2014).

- By focusing on continued growth, supporters of the green economy fail to take account of the fact that, that there might be limits to growth (Victor and Jackson, 2012), and that growth might not be the solution but part of the problem (e.g. Martínez-Alier et al., 2010).

- The limited impact of green policy seen in the past years is the result of a lacking commitment to greening growth and goals that are not radical enough. Hence, it often constitutes no more than 'green-washing' (Borel-Saladin and Turok, 2013). 
- The concept of the green economy begs the question of whether resilient and sustainable economies are achievable without the absolute decoupling of economic growth from environmental impacts (Ward et al., 2016).

- Rebound effects have generally (over)compensated efficiency gains (Druckman et al., 2011; Sorrell, 2007)

- A path where only Europe pursues a more resource efficient path and the rest of the world not, might also lead to an outsourcing of environmental problems of environmental problems to other countries outside of Europe (e.g. carbon leakage).

- Individual purchasing of green products mostly results in only limited ecological improvements (Hobson, 2002).

The Civil Society leads scenario is a more locally-led story, with primacy of individuals, NGOs, activist groups, social and grass-roots technology movements, as well as municipal authorities. Bottom-up voluntary changes in behaviour and practices drive resource efficiency and decarbonisation. The notion that citizens (individually and collectively) are important actors in accelerating transitions is becoming increasingly important in light of limited state-led efforts (Schmitz and Scoones, 2015). There are a number of actions across all major consumption areas that individuals can undertake to live more sustainably (Schanes et al., 2016b). This scenario predominantly involves 'direct reduction' behaviours which refer to reducing the overall demand for products or services, and is highly effective in reducing environmental impacts (Druckman and Jackson, 2010; Schanes et al., 2016b). Movements that are already in place and that strive to reduce consumption include the 'voluntary simplicity' movement (Ballantine and Creery, 2010), or the 'downshifting' movement (Hamilton, 2010). People are reshaping one's own lifestyle according to certain sustainability, political or ethical principles (Haenfler et al., 2012; Micheletti and Stolle, 2010).However, changing individual behaviour and practices are fairly tricky to realise since they are bound by the social context, cultures, and institutions, and are driven and shaped by corporate and government practices (Evans, 2011; O'Rourke and Lollo, 2015). Targeting consumers to act environmentally responsible is debated in political economy terms as the 'privatisation and individualisation of responsibility for environmental problems', which 'shifts blame from state elites and powerful producer groups to amorphous culprits like " human nature" or " all of us"' (Maniates, 2001, p.57).

Besides individual action, groupings of people striving for collective change can have enormous power to initiate powerful bottom-up solutions in e.g. community agriculture, organic farming and community based energy initiatives that have later garnered state and private support (e.g. Grabs et al., 2016; Hargreaves et al., 2013; Ornetzeder and Rohracher, 2013; Seyfang and Smith, 2007). Governments play a key role in supporting such changes by providing supportive conditions and incentives for community involvement. Though the power and outreach of local initiatives and so called grass-roots technology movements that draw on people's own knowledge, alternative technologies, and local experimentation is increasing, they often remain on the sidelines of foresight exercises and innovation policies (Berkhout et al., 2003; Smith et al., 2014). Altogether, this scenario exhibits a range of challenges:

- It is disputed whether individuals are willing and/or able to make the necessary voluntary changes that will transform the market and society in a more resource efficient and sufficient direction (Valor, 2008).

- Directly reducing overall consumption on an individual level turns out to be not that easy at all (Cherrier, 2009). 
- On an individual level, it overrates individuals' ability to make informed decisions and overestimates their power to trigger mitigation efforts along the supply chain through their purchasing power (Grunwald, 2010; Maniates, 2001; Schanes et al., 2016a).

- Changes in individual behaviour e.g. energy saving behaviours, do not necessarily result in a significant reduction in total energy use because the freed-up emission certificates can be used by energy intensive producers (Grunwald, 2010).

- Sufficiency strategies are also subject to rebound effects and backfire (Alcott, 2008; Figge et al., 2014).

- For governments, corporations, and ultimately individuals, efforts aiming at decreasing consumption are shaped by a fear that low or no growth will cause negative economic and social impacts e.g. in employment, profits, stock prices and taxes.

- Current configurations of power drive overconsumption and create barriers against attempts to make the economic processes and society more sustainable and resource-conserving (Fuchs et al., 2016).

- Incumbent interests favour a large technology-focused approach, rather than linking technology to more radical transformations.

- Community based solutions often face considerable challenges in growing and are often unable to translate into mainstream solutions, and to effectively trigger social and environmental change (Busa and Garder, 2015; Feola and Nunes, 2014; Smith et al., 2014).

- So far, little is known about the actual contribution community based solutions can make in preventing or mitigating negative impacts on the environment (Middlemiss and Parrish, 2010).

Changes in individual behaviour and practices are difficult to realize, and it is implausible that they would occur without broader initiatives to change systems of production and consumption. They require moving from single individuals making minor changes in their daily lives, to broader culture changes and to truly fundamental societal change (Akenji, 2014; Foxon, 2013; O'Rourke and Lollo, 2015). Hence, individual behaviour change cannot and should not be a substitute for (international) political efforts.

\section{Concluding remarks}

We have developed three scenarios using a combined approach of creating exploratory scenarios to provide the socio-economic context for telling stories about how a desired future end-point of a resource efficient economy could be achieved. The process of developing both the desired end-point and the scenarios was complex, since it involved a lot of desk-top research by the project team as well as workshops with a diverse range of stakeholders, who provided their own perspectives on both the desired end-point and the ways that this could be achieved. Overall, this combined approach was successful, because the target to be achieved in the future was clear and the socio-economic context provided by the three scenarios was strongly differentiated. Similar to Höjer et al. (2011) we found that stakeholders have difficulty with thinking outside the box and beyond current path. Suggestions for actions are often not radical enough to achieve ambitious resource-efficiency targets. Beyond that, the participatory element of the process was limited to two short workshops that limited the input of stakeholders. Increasing the participatory nature of the approach was, however, not possible within the time and budget constraints of the project and because the stakeholders themselves cannot devote large amounts of time to this kind of research activity.

The scenarios show that there could be different plausible ways to achieve a resource-efficient economy depending on the governance approach taken: top-down agreements, market-based technological solutions and bottom-up attention to both efficiency and sufficiency. 
Global Cooperation applies a top-down approach to solving problems. In its extreme form, an allencompassing blueprint is developed and executed in an orderly, planned and stringently controlled fashion, all under the guidance of a central node.

In Europe Goes Ahead, a scenario that is not often considered in scenario exercises like this, realizing resource efficiency becomes a matter of channelling individual incentives in the right direction but leaving a great degree of freedom for individuals and groups to develop their own preferred solutions.

Civil Society Leads is characterized by operating in social groups without excessively binding rules.

The analysis of these three scenarios shows that resource use will be shaped by, and embedded within, a complex web of actions and decisions by different actors that participate in resource governance, including governments, intergovernmental organisations, firms, non-governmental organisations and diverse communities within civil society (Biermann and Pattberg, 2008).

All three scenarios highlight the importance of collaboration, but at different levels. In the Global Cooperation scenario there are well-established global cooperation and agreements, while the Europe Goes Ahead scenario is based on collective arrangements on a regional level - the European Union. In the third scenario, Civil Society Leads, the focus is on decentralisation and local control embedded in global networks. While both the first and the second scenario are characterized by a strong orientation towards ground-breaking green technology and innovation, the third scenario primarily builds on changes towards a greater sense of individual responsibility, more resource-efficient and sufficient lifestyles that are more socially embedded, located in communities or workplaces. Here green technologies support behavioural changes, but are less important than in the former two scenarios. Therefore, in two of the scenarios changes are driven by top-down approaches, while in the third, empowered citizens stimulate social change.

In reality, the future could evolve as a combination of elements of these scenario narratives. Indeed a mixture of governance approaches might be necessary to achieve ambitious resource efficiency targets. No single actor or governance model has the capacity to tackle global issues such as growing resource use or climate change. In a globalized economy, managing and monitoring natural resources in a sustainable manner must happen at different scales, from local, regional, national to global (Bringezu et al., 2016). Still, global governance including shared commitments and goals for absolute resource reductions is a crucial element to spur efforts on different spatial levels. In the end, focusing on alliances and cooperation between different scales and different actors from public, corporate, private and civic actors to initiatives becomes the central concept in accelerating transformations to sustainability (Scoones et al., 2015). Interventions and policies must go beyond relative decoupling via technological improvements and changing individual consumer behaviour and, instead, support initiatives to change systems of production and consumption across the whole of society (Akenji, 2014; O'Rourke and Lollo, 2015). It must encompass local action such as grassroots innovation movements and community based solutions in multi-scale approaches. Grassroots innovation movements provide spaces for collective action that can enhance and complement innovation pathways to more sustainable futures (Leach et al., 2012; Smith et al., 2014). In addition, a serious move towards a resource-efficient global economy requires a central connection of global politics and local action.

As pointed out in the introduction, the scenario narratives and analysis of the challenges that each scenario poses aim to inform policy-makers, firms and civil society actors. The narratives demonstrate that resource efficiency, and in some cases resource sufficiency, could be achieved within diverse economic and social structures in Europe. The question that arises in this context relates to a much deeper debate on what kind of future we, as a society, want and where our priorities lie (Foxon, 2013). By developing three different scenarios for a resource-efficient society, the paper intends to open up, 
trigger critical discussions on framings of alternative futures, and highlight the challenges but also the opportunities that each plausible future poses.

\section{Acknowledgements}

This project has received funding from the European Union's Seventh Programme for research, technological development and demonstration under grant agreement No 308371. We especially thank Stefan Giljum, Franziska Hartwig and Fritz Hinterberger and all our colleagues of the POLFREE project for fruitful discussions and valuable contributions to this work. We also thank our two independent reviewers for the careful reading of the paper, thoughtful comments, and critical feedback. 


\section{References}

Adger, W.N., Jordan, A., 2009. Governing sustainability. Cambridge University Press Cambridge. Akenji, L., 2014. Consumer scapegoatism and limits to green consumerism. Journal of Cleaner Production 63, 13-23.

Alcott, B., 2008. The sufficiency strategy: Would rich-world frugality lower environmental impact? Ecological Economics 64, 770-786.

Bahn-Walkowiak, B., Steger, S., 2015. Resource targets in Europe and worldwide: An overview. Resources 4, 597-620.

Ballantine, P.W., Creery, S., 2010. The consumption and disposition behaviour of voluntary simplifiers. Journal of Consumer Behaviour 9, 45-56.

Behrens, A., Giljum, S., Kovanda, J., Niza, S., 2007. The material basis of the global economy. Ecological Economics 64, 444-453.

Berkhout, F., Leach, M., Scoones, I., 2003. Shifting perspectives in environmental social science. Negotiating Environmental Change: New Perspectives from Social Science, 1-31.

Biermann, F., Pattberg, P., 2008. Global environmental governance: Taking stock, moving forward. Annual Review of Environment and Resources 33, 277-294.

BIO Intelligence Service, 2012. Assessment of Resource Efficiency Indicators and Targets. Final report prepared for the European Commission, DG Environment.

Bleischwitz, R., Bettina, B.-W., Felix, E., Heidi, F., Lili, F., 2012. International Resource Politics: New challenges demanding new governance approaches for a green economy.

Borel-Saladin, J.M., Turok, I.N., 2013. The Green Economy: Incremental Change or Transformation? Environmental Policy and Governance 23, 209-220.

Börjeson, L., Höjer, M., Dreborg, K.-H., Ekvall, T., Finnveden, G., 2006. Scenario types and techniques: towards a user's guide. Futures 38, 723-739.

Bringezu, S., Potočnik, J., Schandl, H., Lu, Y., Ramaswami, A., Swilling, M., Suh, S., 2016. Multi-Scale Governance of Sustainable Natural Resource Use-Challenges and Opportunities for Monitoring and Institutional Development at the National and Global Level. Sustainability 8, 778.

Busa, J.H., Garder, R., 2015. Champions of the Movement or Fair-weather Heroes? Individualization and the (A)politics of Local Food. Antipode 47, 323-341.

Cambridge Econometrics, 2011. Sustainability Scenarios for a Resource Efficient Europe. Final Report prepared for European Commission, DG Environment. .

Cherrier, H., 2009. Anti-consumption discourses and consumer-resistant identities. Journal of Business Research 62, 181-190.

Conte Grand, M., 2016. Carbon emission targets and decoupling indicators. Ecological Indicators 67, 649-656.

Distelkamp, M., Meyer, M., 2017. Pathways to a Resource-Efficient and Low-Carbon Europe. Ecological Economics.

Druckman, A., Chitnis, M., Sorrell, S., Jackson, T., 2011. Missing carbon reductions? Exploring rebound and backfire effects in UK households. Energy Policy 39, 3572-3581.

Druckman, A., Jackson, T., 2010. The bare necessities: How much household carbon do we really need? Ecological Economics 69, 1794-1804.

European Climate Foundation, 2010. Roadmap 2050: Practical guide to a prosperous, low carbon Europe. Technical \& Economic Analysis - Full Report. Brussels: ECF.

European Climate Foundation, 2011. Power perspectives 2030: On the road to a decarbonised power sector.

European Commission, 2010. EUROPE 2020. A strategy for smart, sustainable and inclusive growth, Brussels.

European Commission, 2011. Roadmap to a Resource Efficient Europe. COM (2011) 571.

Evans, D., 2011. Beyond the throwaway society: ordinary domestic practice and a sociological approach to household food waste. Sociology, 0038038511416150. 
Fedrigo-Fazio, D., Schweitzer, J.-P., ten Brink, P., Mazza, L., Ratliff, A., Watkins, E., 2016. Evidence of Absolute Decoupling from Real World Policy Mixes in Europe. Sustainability 8, 517.

Feola, G., Nunes, R., 2014. Success and failure of grassroots innovations for addressing climate change: The case of the Transition Movement. Global Environmental Change 24, 232-250.

Figge, F., Young, W., Barkemeyer, R., 2014. Sufficiency or efficiency to achieve lower resource consumption and emissions? The role of the rebound effect. Journal of Cleaner Production 69, 216-

224.

Foxon, T.J., 2013. Transition pathways for a UK low carbon electricity future. Energy Policy 52, 10-24. Fuchs, D., Di Giulio, A., Glaab, K., Lorek, S., Maniates, M., Princen, T., Røpke, I., 2016. Power: the missing element in sustainable consumption and absolute reductions research and action. Journal of Cleaner Production 132, 298-307.

Giljum, S., Dittrich, M., Lieber, M., Lutter, S., 2014. Global patterns of material flows and their socioeconomic and environmental implications: a MFA study on all countries world-wide from 1980 to 2009. Resources 3, 319-339.

Grabs, J., Langen, N., Maschkowski, G., Schäpke, N., 2016. Understanding role models for change: a multilevel analysis of success factors of grassroots initiatives for sustainable consumption. Journal of Cleaner Production 134, 98-111.

Grunwald, A., 2010. Wider die Privatisierung der Nachhaltigkeit-Warum ökologisch korrekter Konsum die Umwelt nicht retten kannAgainst Privatisation of Sustainability-Why Consuming Ecologically Correct Products Will Not Save the Environment. GAIA-Ecological Perspectives for Science and Society 19, 178-182.

Haenfler, R., Johnson, B., Jones, E., 2012. Lifestyle movements: Exploring the intersection of lifestyle and social movements. Social Movement Studies 11, 1-20.

Hamilton, C., 2010. Consumerism, self-creation and prospects for a new ecological consciousness. Journal of Cleaner Production 18, 571-575.

Hargreaves, T., Hielscher, S., Seyfang, G., Smith, A., 2013. Grassroots innovations in community energy: The role of intermediaries in niche development. Global Environmental Change 23, 868-880. Hobson, K., 2002. Competing discourses of sustainable consumption: Does the'rationalisation of lifestyles' make sense? Environmental politics 11, 95-120.

Höjer, M., Gullberg, A., Pettersson, R., 2011. Backcasting images of the future city-Time and space for sustainable development in Stockholm. Technological Forecasting and Social Change 78, 819-834. Jäger, J., Rothman, D., Anastasi, C., Kartha, S., van Notten, P., 2007. Training Module 6, Scenario development and analysis. GEO Resource Book: A training manual on integrated environmental assessment and reporting. UNEP \& IISD, Nairobi.

Kok, K., Hesselbjerg Christensen, J., Sloth Madsen, M., Pedde, S., Gramberger, M., Jäger, J., Carter, T., 2015. Evaluation of existing climate and socio-economic scenarios including a detailed description of the final selection. Deliverable 2.1 IMPRESSIONS project. http://www.impressions-

project.eu/documents/1/ (accessed on 15.02.2016).

Leach, M., Rockström, J., Raskin, P., Scoones, I., Stirling, A.C., Smith, A., Thompson, J., Millstone, E., Ely, A., Arond, E., Folke, C., Olsson, P., 2012. Transforming Innovation for Sustainability. Ecology and Society 17.

Lorek, S., Spangenberg, J.H., 2014. Sustainable consumption within a sustainable economy - beyond green growth and green economies. Journal of Cleaner Production 63, 33-44.

Maniates, M.F., 2001. Individualization: Plant a tree, buy a bike, save the world? Global environmental politics 1, 31-52.

Martínez-Alier, J., Pascual, U., Vivien, F.-D., Zaccai, E., 2010. Sustainable de-growth: Mapping the context, criticisms and future prospects of an emergent paradigm. Ecological economics 69, 17411747.

Micheletti, M., Stolle, D., 2010. Vegetarianism-A lifestyle politics. Creative participation:

Responsibility-taking in the political world, 125-145.

Middlemiss, L., Parrish, B.D., 2010. Building capacity for low-carbon communities: The role of grassroots initiatives. Energy Policy 38, 7559-7566. 
Milojević, I., Inayatullah, S., 2015. Narrative foresight. Futures 73, 151-162.

O'Rourke, D., Lollo, N., 2015. Transforming consumption: From decoupling, to behavior change, to system changes for sustainable consumption. Annual Review of Environment and Resources 40, 233259.

O'Brien, M., Hartwig, F., Schanes, K., Kammerlander, M., Omann, I., Wilts, H., Bleischwitz, R., Jäger, J., 2014. Living within the safe operating space: a vision for a resource efficient Europe. European Journal of Futures Research 2, 1-11.

O'Keefe, M., Jäger,J., Hartwig, F., Armeni, C., Bleischwitz, R., 2014. Report on global governance for resource efficient economies. Deliverable 2.5 of the POLFREE Project. http://www.ucl.ac.uk/polfree/publications (accessed on 15.02.2016).

Ornetzeder, M., Rohracher, H., 2013. Of solar collectors, wind power, and car sharing: comparing and understanding successful cases of grassroots innovations. Global Environmental Change 23, 856-867. Peterson, G.D., Cumming, G.S., Carpenter, S.R., 2003. Scenario planning: a tool for conservation in an uncertain world. Conservation biology 17, 358-366.

Quist, J., Thissen, W., Vergragt, P.J., 2011. The impact and spin-off of participatory backcasting: From vision to niche. Technological Forecasting and Social Change 78, 883-897.

Quist, J., Vergragt, P., 2006. Past and future of backcasting: The shift to stakeholder participation and a proposal for a methodological framework. Futures 38, 1027-1045.

Raskin, P., Banuri, T., Gallopin, G., Gutman, P., Hammond, A., Kates, R., Swart, R., 2002. Great transition. Umbrüche und Übergänge auf dem Weg zu einer planetarischen Gesellschaft, Materialien Soziale Ökologie 20.

Raven, P.G., Elahi, S., 2015. The New Narrative: Applying narratology to the shaping of futures outputs. Futures 74, 49-61.

Robinson, J., 2003. Future subjunctive: backcasting as social learning. Futures 35, 839-856.

Robinson, J.B., 1990. Futures under glass: a recipe for people who hate to predict. Futures $22,820-$ 842.

Rockström, J., Steffen, W., Noone, K., Persson, Å., Chapin, F.S., Lambin, E.F., Lenton, T.M., Scheffer, M., Folke, C., Schellnhuber, H.J., 2009. A safe operating space for humanity. nature 461, 472-475. Rothman, D.S., 2008. A survey of environmental scenarios., in: Alcamo, J. (Ed.), Environmental futures: the practice of environmental scenario analysis. Elsevier.

Schaffartzik, A., Mayer, A., Gingrich, S., Eisenmenger, N., Loy, C., Krausmann, F., 2014. The global metabolic transition: Regional patterns and trends of global material flows, 1950-2010. Global Environmental Change 26, 87-97.

Schanes, K., Dobernig, K., Gözet, B., 2016a. Climate Change \& Consumption - An Inseparable Couple? Kurswechsel Klimapolitik und Systemwandel, Heft 3/2016.

Schanes, K., Giljum, S., Hertwich, E., 2016b. Low carbon lifestyles: A framework to structure consumption strategies and options to reduce carbon footprints. Journal of Cleaner Production 139, 1033-1043.

Schmitz, H., Scoones, I., 2015. Accelerating sustainability: why political economy matters. IDS. Scoones, I., Leach, M., Newell, P., 2015. The politics of green transformations. Routledge.

Seyfang, G., Smith, A., 2007. Grassroots innovations for sustainable development: Towards a new research and policy agenda. Environmental politics 16, 584-603.

Smith, A., Fressoli, M., Thomas, H., 2014. Grassroots innovation movements: challenges and contributions. Journal of Cleaner Production 63, 114-124.

Sorrell, S., 2007. The Rebound Effect: an assessment of the evidence for economy-wide energy savings from improved energy efficiency. UK Energy Research Centre London.

Steffen, W., Richardson, K., Rockström, J., Cornell, S.E., Fetzer, I., Bennett, E.M., Biggs, R., Carpenter, S.R., de Vries, W., de Wit, C.A., 2015. Planetary boundaries: Guiding human development on a changing planet. Science $347,1259855$.

Sverdrup, H.U., Ragnarsdottir, K.V., Koca, D., 2017. An assessment of metal supply sustainability as an input to policy: security of supply extraction rates, stocks-in-use, recycling, and risk of scarcity.

Journal of Cleaner Production 140, 359-372. 
UNEP, 2002. Global Environment Outlook 3: Past, present and future perspectives. United Nations Environment Programme, Nairobi. .

UNEP, 2011. Decoupling natural resource use and environmental impacts from economic growth, $A$ Report of the Working Group on Decoupling to the International Resource Panel. Fischer-Kowalski, M., Swilling, M., von Weizsäcker, E.U., Ren, Y., Moriguchi, Y., Crane, W., Krausmann, F., Eisenmenger, N., Giljum, S., Hennicke, P., Romero Lankao, P., Siriban Manalang, A. United Nations Environment Programme.

UNEP, 2014. Decoupling 2: technologies, opportunities and policy options. A Report of the Working Group on Decoupling to the International Resource Panel. von Weizsäcker, E.U., de Larderel, J, Hargroves, K., Hudson, C., Smith, M., Rodrigues, M.

Valor, C., 2008. Can consumers buy responsibly? Analysis and solutions for market failures. Journal of Consumer Policy 31, 315-326.

Van Notten, P.W., Rotmans, J., Van Asselt, M.B., Rothman, D.S., 2003. An updated scenario typology. Futures 35, 423-443.

van Vliet, M., Kok, K., 2015. Combining backcasting and exploratory scenarios to develop robust water strategies in face of uncertain futures. Mitigation and adaptation strategies for global change 20, 43-74.

Victor, P.A., Jackson, T., 2012. A commentary on UNEP's green economy scenarios. Ecological Economics 77, 11-15.

Ward, J.D., Sutton, P.C., Werner, A.D., Costanza, R., Mohr, S.H., Simmons, C.T., 2016. Is decoupling GDP growth from environmental impact possible? PloS one 11, e0164733.

WBCSD, 2010. Vision 2050: The new agenda for business. World Business Council for Sustainable Development Conches-Geneva.

WBGU, 2011. World in transition: a social contract for sustainability. Berlin: German Advisory Council on Global Change, 1-391.

Zürn, M., 2004. Global Governance and Legitimacy Problems. Government and Opposition 39, 260 287. 